\title{
Clinical Characteristics, Management, and Treatment Outcomes of Primary Hypophysitis: A Monocentric Cohort
}

Authors

Seda Hanife Oguz ${ }^{1}$, Figen Soylemezoglu², Suleyman Nahit Sendur ${ }^{1}$, Melike Mut ${ }^{3}$, Kader Karli Oguz ${ }^{4}$, Selcuk Dagdelen ${ }^{1}$, Tomris Erbas ${ }^{1}$

Affiliations

1 Department of Endocrinology and Metabolism, Hacettepe University Medical School, Ankara, Turkey

2 Department of Pathology, Hacettepe University Medical School, Ankara, Turkey

3 Department of Neurosurgery, Hacettepe University Medical School, Ankara, Turkey

4 Department of Radiology, Hacettepe University Medical School, Ankara, Turkey

Key words

hypophysitis, primary hypophysitis, hypopituitarism, immunoglobulin G4, pituitary adenoma, apoplexy

received $\quad 29.10 .2019$

accepted 27.01.2020

Bibliography

DOI https://doi.org/10.1055/a-1113-7777

Horm Metab Res 2020; 52: 220-227

(c) Georg Thieme Verlag KG Stuttgart · New York

ISSN 0018-5043

Correspondence

Seda Hanife Oguz

Department of Endocrinology and Metabolism, Hacettepe

University Medical School

06100, Hacettepe, Ankara

Turkey

Tel.: + 90312305 1707, Fax: + 903123051707

shoguz@gmail.com

Supplementary Material for this article is available online at http://www.thieme-connect.de/products.

\section{ABSTRACT}

Primary hypophysitis ( $\mathrm{PH}$ ) is a rare autoimmune inflammatory disease of the pituitary gland. The aim of the study was to evaluate clinical characteristics, disease management, and outcomes of cases with $\mathrm{PH}$. Medical records of $\mathrm{PH}$ patients admitted to Hacettepe University Hospital between 1999 and 2017 were analyzed retrospectively. Paraffin-embedded pathology blocks were obtained for both re-examination and IgG4 immunostaining. Twenty $\mathrm{PH}$ patients ( 15 females, 5 males) were evaluated. Mean age at diagnosis was $41.5 \pm 13.4$ years. Some form of hormonal disorder was present in $63.2 \%$ of cases, hypogonadism (66.6\%) being the most common. Panhypopituitarism was present in $36.8 \%$. All patients had pituitary gland enlargement on magnetic resonance imaging; stalk thickening and loss of neurohypophyseal bright spot were present in 17.6 and $23.5 \%$, respectively. Lymphocytic hypophysitis was the most common histopathological subtype (50\%). Among pathology specimens available for IgG and IgG4 immunostaining ( $n=10)$, none fulfilled the criteria for IgG4-related hypophysitis. Four patients were given glucocorticoid treatment in diverse protocols; as initial therapy in 3 . Sixteen cases underwent surgery, 7 of whom due to neuro-ophthalmologic involvement. Only 1 patient was observed without any intervention. Reduction of pituitary enlargement was seen in all surgical and glucocorticoid treated cases. None of the surgical patients showed hormonal improvement while one case in glucocorticoid group improved. $\mathrm{PH}$ should be considered in the differential diagnosis of sellar masses causing hormonal deficiencies. MRI findings are usually helpful, but not yet sufficient for definitive diagnosis of $\mathrm{PH}$. Treatment usually improves symptoms and reduces sellar masses while hormonal recovery is less common.

\section{Introduction}

Primary hypophysitis $(\mathrm{PH})$ is a rare autoimmune disease caused by inflammatory infiltration of the pituitary gland, which can result in transient or permanent endocrine dysfunction. The annual incidence was reported to be 1 in 7-9 million cases, and several studies of retrospective re-analysis of surgical pituitary specimens confirmed the low overall incidence of $0.4 \%$ [1].
Histopathological examination is the gold standard for PH diagnosis, however, 'clinical' diagnosis can be made by assessment of symptoms, hormonal profile and magnetic resonance imaging (MRI) characteristics together. It is reported that about one third of the cases are diagnosed in this manner [2]. Natural course of the disease has a very large spectrum: either spontaneous resolution or permanent endocrine dysfunction are possible [3]. Medical therapy (most commonly glucocorticoids) has been increasingly used 
by clinicians, therefore the role for surgery has been gradually decreasing in recent years [4].

Here we aim to contribute to current literature by analyzing clinical features of primary hypophysitis cases over a time frame of 18 years diagnosed in a single tertiary medical center which serves approximately 1600 patients with pituitary disorders annually. We evaluated diagnostic challenges and our therapeutic management experiences of both histopathologically and 'clinically' identified cases.

All procedures performed in the study were in accordance with the ethical standards of the institutional research committee (GO 17-170) and with the Helsinki declaration.

\section{Subjects and Methods}

Medical records of $20 \mathrm{PH}$ patients admitted to Hacettepe University Hospital between August 1999 and September 2017 were analyzed retrospectively. Considering the low incidence of the disease, we included all cases regardless of follow-up duration. Four out of $20 \mathrm{PH}$ cases were diagnosed according to clinical, hormonal and radiological findings whereas 16 had histopathological confirmation. Secondary causes of hypophysitis were ruled out with appropriate tests in all clinically diagnosed $\mathrm{PH}$ patients; granulomatous vasculitis, sarcoidosis and Langerhans cell histiocytosis were excluded by related diagnostic criteria [5] and PPD or Quantiferon test was performed to rule out tuberculosis. None of the subjects were receiving immune check point inhibitors or other targeted therapies associated with hypophysitis. Anti-pituitary antibodies were regrettably not checked. Due to retrospective nature of the study, some of the patients lacked detailed evaluations for accompanying autoimmune diseases.

MRI and hormone test results were reviewed from patient files. Assessment of pituitary hormonal disorders were made according to accessible data, dynamic tests if present. Hormonal replacement therapies for hypocortisolism, hypothyroidism, and hypogonadism were set correspondingly. Paraffin-embedded pathology blocks were obtained from pathology archive for both re-examination and IgG4 immunostaining. IgG4-related disease was evaluated according to related criteria [6]: (1) Characteristic organ involvement, (2) Elevated serum IgG4 levels, and (3) Histopathological findings showing (i) marked lymphocyte and plasmocyte cell infiltration and fibrosis; (ii) IgG4-positive plasma cell infiltration: IgG4 to IgG ratio $>40 \%$ and IgG4-positive plasma cells per high-powered field (HPF) $>10 \%$. According to these criteria, cases meeting all three are defined as definite, cases meeting first and second criteria as possible, and cases meeting first and third criteria as probable lgG4-related disease.

We assessed treatment outcomes according to symptom recovery and follow-up MRI as well as hormonal findings. Disease recurrence was defined as returning symptoms and/or progression in follow-up MRI.

SPSS-23 program was used for statistical analysis. Normally distributed variables were given as mean values with standard deviations while non-normally distributed variables were given as median values with ranges. $\mathrm{p}$-Values less than 0.05 were considered statistically significant.
- Table 1 Characteristics, pre-treatment endocrine findings, and magnetic resonance imaging (MRI) findings of primary hypophysitis patients.

\begin{tabular}{|c|c|c|}
\hline & & Total $\mathbf{n}$ \\
\hline Mean age at diagnosis (years \pm SD) & $41.5 \pm 13.4$ & 20 \\
\hline Female sex (n, \%) & $15(75 \%)$ & 20 \\
\hline Median time to diagnosis (months) & $18(1-120)$ & 19 \\
\hline Referral symptoms (n, \%) & & 19 \\
\hline Headache & $12(63.2 \%)$ & \\
\hline $\begin{array}{l}\text { Decreased libido/menstrual } \\
\text { irregularities }\end{array}$ & $9(47.4 \%)$ & \\
\hline Visual disturbance (any) & $7(36.8 \%)$ & \\
\hline Polyuria/polydipsia & $6(31.6 \%)$ & \\
\hline Nausea & $2(10.5 \%)$ & \\
\hline Fatigue & $2(10.5 \%)$ & \\
\hline Hormonal disorders, any (n, \%) & $12(63.1 \%)$ & 19 \\
\hline Panhypopituitarism & $7(39 \%)$ & 19 \\
\hline Hypogonadism & $12(66 \%)$ & 18 \\
\hline Hypothyroidism & $11(61 \%)$ & 18 \\
\hline Hypocortisolism & $7(39 \%)$ & 18 \\
\hline Hyperprolactinemia & $6(31.5 \%)$ & 19 \\
\hline Diabetes insipidus & $5(28 \%)$ & 18 \\
\hline GH deficiency & $4(21 \%)$ & 19 \\
\hline MRI contrast pattern & & 17 \\
\hline Homogenous contrast enhancement & $4(23.5)$ & \\
\hline $\begin{array}{l}\text { Heterogeneous contrast enhance- } \\
\text { ment }\end{array}$ & $2(11.7)$ & \\
\hline Peripheral contrast enhancement & $2(11.7)$ & \\
\hline $\begin{array}{l}\text { Infundibular contrast enhancement } \\
\text { only }\end{array}$ & $1(5.9)$ & \\
\hline Hypo-enhancement & $2(11.7)$ & \\
\hline Not reported ${ }^{*}$ & $6(35.3)$ & \\
\hline \multicolumn{3}{|l|}{ Other MRI findings } \\
\hline Infundibular thickening & $3(17.6)$ & \\
\hline $\begin{array}{l}\text { Loss of neurohypophyseal bright } \\
\text { spot }\end{array}$ & $4(23.5)$ & \\
\hline $\begin{array}{l}\text { Optic chiasm or nerve compression } \\
\text { (any) }\end{array}$ & $7(41.2)$ & \\
\hline
\end{tabular}

SD: Standard deviation, GH: Growth hormone. " Pre-operative MRI was not performed in our center and/or did not report contrast enhancement pattern.

\section{Results}

\section{Clinical presentation and endocrinological evaluation}

Twenty patients (15 females, 5 males) with $\mathrm{PH}$ were included ( $\triangleright$ Table 1). Mean age at diagnosis were $34.6 \pm 15.0$ vs. $43.9 \pm 12.5$ years in male and female patients, respectively; $p=0.19$. Median time from symptom onset to diagnosis was 18 months (1-120). Since all data except pathological examination and age was miss- 
ing for one patient, 19 patients were included in further analysis. Most common presenting symptoms were headache $(n=12$, $63.2 \%$ ) and symptoms associated with hypogonadism; such as decreased libido in male and menstrual irregularities in female patients ( $n=9,47.4 \%$ ). Visual disturbance (photophobia, hemianopsia, etc.) and polyuria/polydipsia were also common ( $\triangleright$ Table 1 ). Among six patients examined for accompanying autoimmune disorders, only one had autoimmune thyroiditis with normal thyroid functions.

At least one form of hormonal disorder was present in 12 out of 19 patients (63.2\%), hypogonadism (66.6\%) and hypothyroidism (61.1\%) being the most common ( $\triangleright$ Table 1$)$. Seven out of 19 patients had panhypopituitarism (36.8\%). Hypocortisolism was found in $38.9 \%$ of the patients $(n=7)$. Posterior hypophyseal involvement was present in five patients (27.8\%): Two of these patients did not have any concurrent anterior pituitary hormonal deficiencies but elevated PRL. Overall, six patients had mildly elevated levels of prolactin (PRL) (31.6\%) ranging between 39.0-69.6 ng/ml (Reference range: $5.18-26.5 \mathrm{ng} / \mathrm{ml})$.

Only one patient was diagnosed subsequent to pregnancy. This 34-year-old patient was admitted with symptoms of visual disturbance one month after child delivery. MRI findings suggested pituitary macroadenoma measuring $14 \times 16 \times 24$ mm which compressed optic chiasm, normal adenohypophysis gland was not visible while neurohypophyseal bright spot was in usual location. The patient was undergone urgent surgery under glucocorticoid coverage, in which only decompression could be made due to very hard pituitary tissue structure. Pathology report came back as lymphocytic hypophysitis. The patient needed prednisolone and levothyroxine replacement postoperatively.

\section{Radiological findings}

MRI findings were obtainable for 17 , but missing for remaining three patients, and they are presented in $>$ Table 1 . According to the radiologic score defined by Gutenberg et al. [7] (age $\leqq 30$ years: -1 , relation to pregnancy: -4 , pituitary volume $\geqq 6 \mathrm{~cm}^{3}:+2$, medium/high gadolinium enhancement: -1 , asymmetry: +3 , loss of posterior pituitary bright spot: -2 , enlarged stalk size: -5 , mucosal thickening: + 2) which suggested scores between -13 to +2 (median -5 ) indicative of $\mathrm{PH}$, only five of our patients were compatible with autoimmune hypophysitis. One out of these 5 cases had a score of -4 due to related pregnancy (as described above) but did not meet any of the other criteria. Remaining four patients had scores ranging -5 to -8 , all of whom were diagnosed 'clinically' as primary hypophysitis: Three cases were given glucocorticoid treatment and one was observed without intervention (described below).

Notably, 'possible hypophysitis' was more frequently reported by radiologists in the recent years compared to early 2000 s. It is also noteworthy that radiological diagnosis was more accurate in patients whose clinical information was provided as 'panhypopituitarism' and preliminary diagnosis as 'hypophysitis' by clinicians. Loss of posterior pituitary bright spot also appeared to be important in radiologists' decision making. Three out of four MRIs showing loss of neurohypophyseal bright spot were reported as possible hypophysitis.

\section{Pathological examination findings}

Pathological assessments of all patients were made by the same experienced neuropathologist (F.S.). Lymphocytic hypophysitis was the histopathological subtype in eight out of 16 patients (50\%). Six cases were diagnosed as granulomatous hypophysitis (37.5\%) while one patient was reported as xantho-granulomatous and one as lymphogranulomatous hypophysitis.

Breakdown of the reticulin fiber network was reported in seven cases. Fibrosis, granuloma formations and multinuclear giant cells were detected in 7 (43.7\%), 7 (43.7\%) and 8 (50\%) patients; respectively. Neither histopathological subtype of $\mathrm{PH}$ nor existence of fibrosis had any association with hormonal deficiencies. Pathological findings indicating the presence of accompanying Rathke's cleft cysts were reported in three lymphocytic hypophysitis cases (18.7\%); none of which was reported in preoperative MRI.

We have examined the pathology specimens prepared from paraffin embedded blocks for $\mathrm{lgG}$ and $\mathrm{lgG} 4$ immunostaining. Out of ten specimens available for this process, none fulfilled the criteria for IgG4-related hypophysitis. However, two patients (31-year-old male and 40-year-old female) had $>10 \mathrm{lgG} 4$ positive plasma cells per one high powered area. Male patient with panhypopituitarism and DI was classified as lymphocytic hypophysitis, pathological findings included fibrosis and marked stromal infiltration with lymphocytes. Histopathology of the female patient with DI and mild hyperprolactinemia was compatible with both granulomatous and lymphocytic hypophysitis; fibrosis was present. Since serum IgG4 levels were regrettably not available in these two cases, these patients may be diagnosed as probable lgG4-related hypophysitis.

\section{Treatment}

Glucocorticoid treatment was given to four patients, as initial therapy in three cases who were diagnosed 'clinically'. Patients treated with glucocorticoid are presented in \ Supplementary Table 1S.

Case 1

Only male patient in this group received methylprednisolone at an initial dose of $60 \mathrm{mg} /$ day intravenous for two weeks, followed by $60 \mathrm{mg} / \mathrm{d}$ orally; the dose was tapered down in a monthly basis to a final dose of $8 \mathrm{mg} /$ day and was stopped after 6 months. Radiologic improvement was detected after 6 months; however, hormonal situation did not improve. Serum IgG4 levels were found to be higher than normal (IgG4: $1100 \mathrm{mg} / \mathrm{l}, \mathrm{N}$ : 39-864; IgG: $1480 \mathrm{mg} / \mathrm{dl}, \mathrm{N}$ : 751-1560). No other organ or system involvement associated with IgG4-related disease has emerged at diagnosis or during follow-up. Therefore, this case was considered as possible IgG4 related hypophysitis. Progression was detected on MRI after 72 months of follow up regarding infundibular thickening $(6 \mathrm{~mm})$, although no further immunosuppressive treatment was planned due to lack of clinical significance. The patient continued hormone replacement therapy for panhypopituitarism and DI.

\section{Case 2}

This female patient was given methylprednisolone $60 \mathrm{mg} /$ day initially, and the dose was tapered down in 3 months. She rapidly became Cushingoid in appearance with concurrent elevated blood glucose and rhabdomyolysis. Although the infundibular thickening shrank to $5 \mathrm{~mm}$ at the end of 3 months, panhypopituitarism and DI 
remained. Due to lack of improvement and Cushingoid adverse effects, cessation of treatment was decided while hormone replacement therapy was sustained.

\section{Case 3}

The other female patient was treated with pulse methylprednisolone $1 \mathrm{~g} /$ day for three days and $60 \mathrm{mg} /$ day deflazacort as maintenance therapy, which was tapered down to as low as $6 \mathrm{mg} /$ day. Desmopressin was given for accompanying DI. After one year of treatment, MRI findings of the patient were completely normal, and both deflazacort and desmopressin therapies were stopped.

\section{Case 4}

Glucocorticoid was given as secondary treatment in this female patient presenting with decreased visual acuity and diplopia. She was given to surgery, which provided decompression of optic chiasm. Pathology report came back as granulomatous hypophysitis. Two months after surgery she was admitted to hospital with headache and relapsed decline in visual acuity of the right eye and was given pulse glucocorticoid treatment which rapidly improved symptoms. However, panhypopituitarism remained.

A total number of 16 cases underwent surgery. Preliminary diagnosis was non-functioning pituitary macroadenoma in nine (56.2\%); macroadenoma, Rathke's cleft cyst or other kind of sellar mass (e. g. craniopharyngioma) in five (31.2\%) patients (data not available in one). Surgery related minor complications such as mild bleeding, cerebrospinal fluid leak, arachnoid membrane rupture was seen in three cases; all were repairable.

One female patient among clinically diagnosed cases presented with headache and diagnosed as $\mathrm{PH}$ according to symptoms and MRI findings (expanded pituitary gland with homogenous contrast enhancement and thickened infundibulum, radiologic score of -5 according to radiologic criteria by Gutenberg et al. [7] at the age of 50 . Hormonal evaluation was completely normal and she was not given any treatment. Her medical history revealed several previous examinations for headache in a time range of 84 months and MRI findings were stable comparing to one year earlier.

\section{Patient Outcomes}

Median follow-up period was 12 months (range: $0-132$ months). Among 15 patients who underwent operation radiological improvement and symptom relief occurred in all, yet none showed hormonal improvement (data not available in one). New hormonal deficiencies emerged in 4 surgical patients: Panhypopituitarism emerged in one of the two patients with completely normal pre-operative endocrine evaluation, and DI in the other. The other two patients with partial endocrine deficiencies needed additional hormone replacements post-operatively $(\triangleright$ Table 2 , Supplemantary Table 1S). Radiologic and symptomatic relapse arose in 1 patient two months after surgery who was treated effectively with glucocorticoid.

Three 'clinically' diagnosed patients received initial glucocorticoid therapy but in diverse protocols. Pituitary enlargement regressed in all, as well as symptoms related to mass effect. The only patient to benefit from glucocorticoid treatment regarding endocrine outcomes was initially given pulse glucocorticoid and longterm low dose glucocorticoid as maintenance therapy. Radiologic recurrence was seen in one patient after 72 months without symptoms ( $\triangleright$ Supplemantary Table 1S).

\section{Discussion}

In this retrospective study, we evaluated characteristics, presenting signs and symptoms, management modalities and treatment outcomes of $20 \mathrm{PH}$ patients diagnosed in our center. In addition, we examined the pathology specimens for $\mathrm{lgG}$ and $\mathrm{lgG} 4$ staining. Main findings of our cohort are presented in > Table 3 comparably with previous single-center case series.

Most common presenting symptom related to $\mathrm{PH}$ has indisputably been headache, as in our series. Visual disturbances according to mass effect are also common, while other symptoms vary depending mainly on existing hormonal deficiencies. Hypogonadism and hypothyroidism were the most common endocrine deficiencies in our series, similar to some previous case series [8, 9]; but more common than that reported in a recent $\mathrm{PH}$ case review $(66 \%$ and $61 \%$ vs. $55 \%$ and $52 \%$, respectively) [10]. Although hypocortisolism has generally been defined as the most common endocrine disorder in $\mathrm{PH}$ (60\%) [10], some case series reported lower incidence as in our cohort $[9,11]$. DI, growth hormone deficiency and mild hyperprolactinemia were also less common in our series than general [10]. Median time from onset of symptoms to diagnosis ranged from 3.5 to 16 months in previous case series [8, 9, 12-15], while it was 18 months in ours ( $\triangleright$ Table 3 ).

Formerly higher female to male ratios in $\mathrm{PH}$ has recently been given as 2.5:1, which was 3 in our case series. Mean age at the time of diagnosis (41.5 years) was also consistent with literature [10]. In our series, female cases were older than males at the time of diag-

- Table 2 Treatment, outcomes, and follow-up of primary hypophysitis patients.

\begin{tabular}{|c|c|c|}
\hline & & Total $\mathbf{n}$ \\
\hline Preliminary diagnosis (n, \%) & & 20 \\
\hline Hypophysitis & $4(20 \%)$ & \\
\hline Other & $16(80 \%)$ & \\
\hline $\begin{array}{l}\text { Preoperative endocrinology consulta- } \\
\text { tion (n, \%) }\end{array}$ & & 19 \\
\hline Yes & $8(42.1 \%)$ & \\
\hline No & $11(57.9 \%)$ & \\
\hline Surgery (n, \%) & & 20 \\
\hline Yes & $16(80 \%)$ & \\
\hline No & $4(20 \%)$ & \\
\hline Surgical complications, any (n, \%) & & 15 \\
\hline Yes & $3(20 \%)$ & \\
\hline No & $12(80 \%)$ & \\
\hline $\begin{array}{l}\text { Post-operatively emerging hormonal } \\
\text { disorders, any (n, \%) }\end{array}$ & $4(26.6 \%)$ & 15 \\
\hline $\begin{array}{l}\text { Improvement of hormonal disorders } \\
\text { in cases treated by steroid ( } n, \%)\end{array}$ & $1(20 \%)$ & 4 \\
\hline Median follow-up (months, range) & $12(0-132)$ & \\
\hline
\end{tabular}


- Table 3 Characteristics, treatment modalities and treatment outcomes of $\mathrm{PH}$ patients comparably with previous single-center case series.

\begin{tabular}{|c|c|c|c|c|c|c|c|c|c|}
\hline & $\begin{array}{l}\text { Leung, } \\
\text { GK. } \\
2004 \\
{[8]}\end{array}$ & $\begin{array}{l}\text { Park, } \\
\text { SM. } 2014 \\
{[11]}\end{array}$ & $\begin{array}{l}\text { Khare, } \\
\text { S. } 2015 \\
{[13]}\end{array}$ & $\begin{array}{l}\text { Imber, BS. } \\
2015 \text { [12] }\end{array}$ & $\begin{array}{l}\text { Chiloiro, } \\
\text { S. } 2017 \\
{[15]}\end{array}$ & $\begin{array}{l}\text { Wang, S. } \\
2017 \text { [9] }\end{array}$ & $\begin{array}{l}\text { Ange- } \\
\text { lousi, } \\
\text { A. } 2018 \\
{[16]}\end{array}$ & $\begin{array}{l}\text { Korkmaz, } \\
\text { OP. } 2019 \\
{[14]}\end{array}$ & $\begin{array}{l}\text { Current } \\
\text { case } \\
\text { series }\end{array}$ \\
\hline Number of patients & 16 & 22 & 24 & 21 & 21 & 50 & 22 & 17 & 20 \\
\hline $\begin{array}{l}\text { Mean age at diagnosis } \\
\text { (years) }\end{array}$ & 47.6 & 48 & 31.5 & 37 & 40 & 37 & 42 & 31 & 41.5 \\
\hline Female to male Ratio & 1 & 3.4 & 7 & 1.6 & 4.2 & 1.9 & 3.4 & 1.4 & 3 \\
\hline $\begin{array}{l}\text { Pregnancy-related } \\
\text { cases }(\mathbf{n})\end{array}$ & 3 & & 1 & 4 & 0 & 8 & 0 & 0 & 1 \\
\hline $\begin{array}{l}\text { Most common } \\
\text { presenting symptom/s } \\
\text { (\%) }\end{array}$ & $\begin{array}{l}\text { Head- } \\
\text { ache } \\
75 \% \\
\text { Lethargy } \\
62 \% \\
\text { Gonadal } \\
\text { dysfunc- } \\
\text { tion } 50 \%\end{array}$ & $\begin{array}{l}\text { Polyuria/ } \\
\text { polydipsia } \\
82 \% \\
\text { Headache } \\
27 \%\end{array}$ & $\begin{array}{l}\text { Headache } \\
83 \%\end{array}$ & $\begin{array}{l}\text { Polyuria/ } \\
\text { polydipsia } \\
52 \% \\
\text { Headache } \\
57 \% \\
\text { Visual } \\
\text { disturbance } \\
52 \% \\
\text { Gonadal } \\
\text { dysfunction } \\
48 \%\end{array}$ & $\begin{array}{l}\text { Polyuria/ } \\
\text { polydipsia } \\
47 \% \\
\text { Headache } \\
24 \% \\
\text { Gonadal } \\
\text { dysfunc- } \\
\text { tion } 47 \%\end{array}$ & $\begin{array}{l}\text { Headache } \\
\text { and visual } \\
\text { distur- } \\
\text { bance }\end{array}$ & $\begin{array}{l}\text { Head- } \\
\text { ache } \\
59 \% \\
\text { Gonadal } \\
\text { dysfunc- } \\
\text { tion } 59 \% \\
\text { Visual } \\
\text { distur- } \\
\text { bance } \\
32 \%\end{array}$ & $\begin{array}{l}\text { Headache } \\
53 \% \\
\text { Polyuria/ } \\
\text { Polydipsia } \\
47 \% \\
\text { Fatigue } \\
41 \%\end{array}$ & $\begin{array}{l}\text { Headache } \\
63 \% \\
\text { Gonadal } \\
\text { dysfunc- } \\
\text { tion } 66 \% \\
\text { Visual } \\
\text { distur- } \\
\text { bance } 37 \% \\
\text { Polyuria/ } \\
\text { Polydipsia } \\
32 \%\end{array}$ \\
\hline $\begin{array}{l}\text { Time to diagnosis } \\
\text { (months) }\end{array}$ & $\begin{array}{l}15.8 \\
(1-60)\end{array}$ & & 10 & $3.5(0.5-60)$ & & $4(1-60)$ & & $12(1-96)$ & $18(1-120)$ \\
\hline \multicolumn{10}{|c|}{ Hormonal deficiencies (\%) } \\
\hline Adrenal & 58 & 36 & 75 & & $\begin{array}{l}\text { (Any kind } \\
\text { of anterior } \\
\text { hormonal } \\
\text { deficiency } \\
\text { in } 81 \% \text { ) }\end{array}$ & 26 & $\begin{array}{l}\text { (Any } \\
\text { kind of } \\
\text { anterior } \\
\text { hormo- } \\
\text { nal } \\
\text { deficien- } \\
\text { cy in } \\
77 \% \text { ) }\end{array}$ & 59 & 39 \\
\hline Thyroid & 50 & 36 & 58.3 & & & 38 & & 53 & 61 \\
\hline Gonadal & 91.6 & 32 & 50 & & & 60 & & 47 & 66 \\
\hline $\mathrm{GH}$ & 43 & 23 & & & & 22 & & 6 & 21 \\
\hline DI & 31 & 82 & 16.7 & 14 & 47.6 & 30.5 & 32 & 47 & 28 \\
\hline Hyperprolactinemia & 37.5 & 23 & 41.6 & 48 & 42.8 & 48 & & 41 & 31 \\
\hline Panhypopituitarism & & & & 57 & 4 & 10 & 23 & 23.5 & 39 \\
\hline $\begin{array}{l}\text { Co-existing autoim- } \\
\text { mune diseases }(\mathbf{n})\end{array}$ & 5 & 2 & & 5 & 13 & 3 & 8 & 2 & 2 \\
\hline \multicolumn{10}{|c|}{ Histopathological type \% } \\
\hline $\mathrm{LH}$ & 77 & 73 & $100(?)$ & 76 & & 100 & 86 & 75 & 50 \\
\hline $\mathrm{GH}$ & 23 & 18 & & 14 & & & & & 37.5 \\
\hline $\mathrm{XGH}$ & & 9 & & & & & 6 & 12.5 & 6 \\
\hline Mixed & & & & & & & & 12.5 & 6 \\
\hline IgG-4 related & 1 & & & 5 & & & 6 & & \\
\hline $\begin{array}{l}\text { Clinically diagnosed } \\
\text { cases (n/\%) }\end{array}$ & 3 & 11 & 15 & 2 & 19 & 22 & 8 & 9 & 4 \\
\hline Surgery (n) & 13 & 5 & 5 & 19 & 2 & 15 & 9 & 7 & 16 \\
\hline Steroid treatment $(\mathrm{n})$ & 8 & 5 & 4 & All & All & 26 & $8^{*}$ & $5^{* *}$ & 4 \\
\hline Observation (n) & & 12 & 11 & None & None & 9 & 5 & 10 & 1 \\
\hline $\begin{array}{l}\text { Duration of follow-up } \\
\text { (months) }\end{array}$ & $\begin{array}{l}30 \\
(2-107)\end{array}$ & $\begin{array}{l}57 \\
(7-138)\end{array}$ & 18 & 28.9 & 12 & $\geq 6$ & 60 & $24(6-84)$ & $12(0-132)$ \\
\hline
\end{tabular}


> Table 3 Continued...

\begin{tabular}{|c|c|c|c|c|c|c|c|c|c|}
\hline & $\begin{array}{l}\text { Leung, } \\
\text { GK. } \\
2004 \\
{[8]}\end{array}$ & $\begin{array}{l}\text { Park, } \\
\text { SM. } 2014 \\
{[11]}\end{array}$ & $\begin{array}{l}\text { Khare, } \\
\text { S. } 2015 \\
{[13]}\end{array}$ & $\begin{array}{l}\text { Imber, BS. } \\
2015 \text { [12] }\end{array}$ & $\begin{array}{l}\text { Chiloiro, } \\
\text { S. } 2017 \\
{[15]}\end{array}$ & $\begin{array}{l}\text { Wang, S. } \\
2017[9]\end{array}$ & $\begin{array}{l}\text { Ange- } \\
\text { lousi, } \\
\text { A. } 2018 \\
{[16]}\end{array}$ & $\begin{array}{l}\text { Korkmaz, } \\
\text { OP. } 2019 \\
{[14]}\end{array}$ & $\begin{array}{l}\text { Current } \\
\text { case } \\
\text { series }\end{array}$ \\
\hline \multicolumn{10}{|l|}{$\begin{array}{l}\text { Relief of symptoms } \\
\text { after treatment \% }\end{array}$} \\
\hline Surgery & 100 & 100 & 100 & & $\begin{array}{l}72.2 \% \text { in } \\
\text { all group }\end{array}$ & 100 & & & 100 \\
\hline Medical & 60 & 100 & & & & 100 & & & 100 \\
\hline Observation & & & & & & 22.2 & & & \\
\hline \multirow[t]{4}{*}{$\begin{array}{l}\text { Radiological improve- } \\
\text { ment in non-surgical } \\
\text { patients }\end{array}$} & NA & $\begin{array}{l}\text { Pituitary } \\
\text { mass } \\
\text { reduction } \\
\text { in } 4 \\
\text { steroid } \\
\text { treated } \\
\text { patients } \\
(80 \%)\end{array}$ & $\begin{array}{l}\text { Pituitary } \\
\text { mass } \\
\text { regressed } \\
\text { in all, } \\
\text { both } \\
\text { steroid } \\
\text { and } \\
\text { observa- } \\
\text { tional } \\
\text { groups }\end{array}$ & $\begin{array}{l}\text { Mass } \\
\text { reduction in } \\
8(50 \%)\end{array}$ & $\begin{array}{l}\text { Radiologic } \\
\text { improve- } \\
\text { ment in } 13 \\
(72.2 \%)\end{array}$ & $\begin{array}{l}\text { Mass } \\
\text { reduction } \\
\text { in all } \\
\text { steroid } \\
\text { treated } \\
\text { patients }\end{array}$ & $\begin{array}{l}\text { Normal } \\
\text { imaging } \\
\text { findings } \\
\text { in } 27 \% \\
\text { of } \\
\text { treat- } \\
\text { ment } \\
\text { group }\end{array}$ & $\begin{array}{l}\text { Improve- } \\
\text { ment in } \\
40 \% \text { and } \\
30 \% \text { of } \\
\text { steroid } \\
\text { and } \\
\text { observa- } \\
\text { tion } \\
\text { groups, } \\
\text { respective- } \\
\text { ly }\end{array}$ & $\begin{array}{l}\text { Pituitary } \\
\text { mass } \\
\text { regressed } \\
\text { in all } \\
\text { steroid } \\
\text { treated } \\
\text { patients }\end{array}$ \\
\hline & & $\begin{array}{l}\text { No change } \\
\text { in } \\
\text { observa- } \\
\text { tion group }\end{array}$ & $\begin{array}{l}\text { Persis- } \\
\text { tent stalk } \\
\text { thicken- } \\
\text { ing in } 13 \\
(68.4 \%)\end{array}$ & $\begin{array}{l}\text { Stable or } \\
\text { worse in } 50 \%\end{array}$ & $\begin{array}{l}\text { (All group } \\
\text { evaluated, } \\
\text { regardless } \\
\text { of surgery) }\end{array}$ & $\begin{array}{l}\text { Spontane- } \\
\text { ous mass } \\
\text { reduction } \\
\text { in } 22.2 \% \\
\text { of } \\
\text { observa- } \\
\text { tion group }\end{array}$ & & & \\
\hline & & & $\begin{array}{l}\text { Near } \\
\text { normal } \\
\text { MRI } \\
\text { findings } \\
\text { in } 2 \\
(10.5 \%)\end{array}$ & $\begin{array}{l}\text { (All group } \\
\text { evaluated, } \\
\text { regardless of } \\
\text { surgery) }\end{array}$ & & & & & \\
\hline & & & $\begin{array}{l}\text { Empty } \\
\text { sella with } \\
\text { thinning } \\
\text { of stalk in } \\
4(21 \%)\end{array}$ & & & & & & \\
\hline $\begin{array}{l}\text { Endocrine improve- } \\
\text { ment, \% }\end{array}$ & & & & $\begin{array}{l}19 \% \text { in all } \\
\text { group }\end{array}$ & $\begin{array}{l}85.7 \% \text { in } \\
\text { all group }\end{array}$ & & & & \\
\hline Surgery & & & 25 & & & 0 & 16.6 & 14.3 & 0 \\
\hline Medical & 0 & 40 & 100 & & & 40.9 & 44.4 & 20 & 20 \\
\hline Observation & & 17 & 100 & & & 22 & 5.5 & 10 & NA \\
\hline Recurrence (n) & 2 & 3 & & 6 & & $\begin{array}{l}46 \% \text { in } \\
\text { medical, } \\
11 \% \text { in } \\
\text { surgical } \\
\text { group }\end{array}$ & 4 & 1 & 2 \\
\hline
\end{tabular}

" Five out of 8 patients received other immunosuppressive agents. " " None received steroid as initial treatment. NA: Not available.

nosis; which is a finding mostly incompatible with previous publications $[2,10,16]$. Although female patients were also older in the case series reported by Khare et al., mean age at diagnosis of overall group was younger than ours (31.5 years) [13]. Even though PH is highly associated with pregnancy [2], only one of our cases was pregnancy-related.

Other autoimmune diseases co-exist with $\mathrm{PH}$ up to $18 \%$ of cases, autoimmune thyroiditis being the most common [2]. However, we could only define one case with concomitant autoimmune thyroiditis. 
Lymphocytic hypophysitis is the most common histological subtype of $\mathrm{PH}$, reported in $68 \%$ of cases. Granulomatous hypophysitis is the second most common variant (20\%) while IgG4-related and xanthomatous hypophysitis are reported in 4 and $3 \%$ of patients, respectively. Mixed pathological characteristics were reported in $4 \%$ [10]. Our findings were consistent with these data. Notably, concurrent Rathke's cleft cysts were defined in three lymphocytic hypophysitis cases in our series. None of these cases had cystic appearance on MRI, but recognized by pathological examination. Simply explained by the triggered inflammatory reaction occurring secondary to cyst rupture, this co-existence was previously reported in other cases of both lymphocytic and xantho-granulomatous hypophysitis [17, 18]. Adrenal insufficiency was reported to be common in patients with Rathke's cleft cysts [19]; however, only one out of three of our cases had adrenal hormone deficiency. Although we performed IgG4 immunostaining in available pathology specimens, it was not achievable to fully evaluate patients regarding IgG4-related hypophysitis due to the retrospective nature of our study.

Previous studies suggested that histopathological confirmation is not always mandatory to diagnose $\mathrm{PH}$, especially if no alternative diagnoses are considered which could change treatment [20]. Cases of 'clinically diagnosed' $\mathrm{PH}$ have been reported more frequently in the literature in recent years, possibly due to expanded awareness. However, the majority of patients are still diagnosed after surgical procedures [10], as in our series. The most common indications for surgery in $\mathrm{PH}$ have been symptoms related to mass effect, such as headache and visual disturbances; but also, diagnostic difficulties. Our study exposed that radiological diagnosis was more accurate when clinicians provide more clinical knowledge for radiologists. Also, loss of posterior pituitary bright spot and thickened infundibulum were associated with more precise diagnosis of $\mathrm{PH}$, like previously been identified as indicative radiological findings for $\mathrm{PH}$ [21]. Nevertheless, yet the best imaging technique available, pituitary MRI alone may not be enough to distinguish $\mathrm{PH}$ from pituitary adenomas [22].

Treatment of $\mathrm{PH}$ targets both hormonal deficiencies and symptoms associated with mass effect. Conservative management has been suggested in asymptomatic patients [2], which was appropriate for one case in our series. While glucocorticoids are the first choice of medical treatment in $\mathrm{PH}$, surgery should be reserved for severe cases having neuro-ophthalmologic findings or cases who are non-responsive to medical treatment [22]. Overall, mass reducing treatments, either surgical or medical, have been reported to improve symptoms and radiological findings in $70-80 \%$ of patients but endocrine deficiencies in only $18 \%$ [2, 10, 23], compatible with our findings. Used in variable doses and duration, Honegger et al. reported radiologic and hormonal improvement in $65 \%$ and $18 \%$ of cases with glucocorticoid treatment, respectively [23]. All glucocorticoid treated patients in our series showed radiologic response. Although some previous case series reported better hormonal response rates to glucocorticoid therapy than ours $[9,11,13,16]$, our rates were similar with others $[12,14,23]$ and better than one [8] ( $\triangleright$ Table 3 ). Out of 16 surgical patients in our series, seven had optic chiasm compression. Although 14 to $25 \%$ recovery of endocrine function in surgical cases was reported in some previous reports $[8,13,16]$, none of our patients showed im- provement in this manner. There was only one case relapsed after surgery, though Honegger et al. reported $25 \%$ recurrence in surgically treated $\mathrm{PH}$ cases [23]. None of our subjects received third-line treatments such as other immunosuppressive agents or radiotherapy.

Our study has some limitations; first of which is the rather high surgery rate. This is mainly a consequence of high occurrence of neuro-ophthalmological involvement, but also of diagnostic difficulties. Another limitation is that glucocorticoid treated patients received different treatment regimes. However, we think that the distinguished regimes may be explicable by the retrospective nature of the study.

In conclusion, we have reported a series of $\mathrm{PH}$ including 20 cases mostly confirmed by histopathology. We have reviewed clinical characteristics and presentations, radiological and endocrine findings as well as disease management and outcomes of the patients comparatively with previous reports. Although few patients received glucocorticoid therapy, we have discussed each case in detail regarding treatment modalities and therapy responsiveness.

\section{Conflict of Interest}

The authors declare that they have no conflict of interest.

References

[1] Mete O, Lopes MB. Overview of the 2017 WHO Classification of Pituitary Tumors. Endocr Pathol 2017; 28: 228-243

[2] Caturegli P, Lupi I, Landek-Salgado M et al. Pituitary autoimmunity: 30 years later. Autoimmun Rev 2008; 7: 631-637

[3] Rivera JA. Lymphocytic hypophysitis: Disease spectrum and approach to diagnosis and therapy. Pituitary 2006; 9: 35-45

[4] Kyriacou A, Gnanalingham K, Kearney T. Lymphocytic hypophysitis: Modern day management with limited role for surgery. Pituitary 2017; 20: $241-250$

[5] Caturegli P, Newschaffer C, Olivi A et al. Autoimmune hypophysitis. Endocr Rev 2005; 26: 599-614

[6] Umehara H, Okazaki K, Nakamura T et al. Current approach to the diagnosis of IgG4-related disease - Combination of comprehensive diagnostic and organ-specific criteria. Mod Rheumatol 2017; 27: 381-391

[7] Gutenberg A, Larsen J, Lupi I et al. A radiologic score to distinguish autoimmune hypophysitis from nonsecreting pituitary adenoma preoperatively. AJNR Am J Neuroradiol 2009; 30: 1766-1772

[8] Leung GK, Lopes MB, Thorner MO et al. Primary hypophysitis: A single-center experience in 16 cases. J Neurosurg 2004; 101: 262-271

[9] Wang S, Wang L, Yao Y et al. Primary lymphocytic hypophysitis: Clinical characteristics and treatment of 50 cases in a single centre in China over 18 years. Clin Endocrinol (Oxf) 2017; 87: 177-184

[10] Caturegli P, Di Dalmazi G, Lombardi M et al. Hypophysitis Secondary to Cytotoxic T-Lymphocyte-Associated Protein 4 Blockade: Insights into Pathogenesis from an Autopsy Series. Am J Pathol 2016; 186: 3225-3235

[11] Park SM, Bae JC, Joung JY et al. Clinical characteristics, management, and outcome of 22 cases of primary hypophysitis. Endocrinol Metab (Seoul) 2014; 29: 470-478

[12] Imber BS, Lee HS, Kunwar S et al. Hypophysitis: A single-center case series. Pituitary 2015; 18: 630-641 
[13] Khare S, Jagtap VS, Budyal SR et al. Primary (autoimmune) hypophysitis: A single centre experience. Pituitary 2015; 18: 16-22

[14] Korkmaz OP, Sahin S, Ozkaya HM et al. Primary hypophysitis: Experience of a Single Tertiary Center. Exp Clin Endocrinol Diabetes. 2019; doi: 10.1055/a-0919-4388 [Epub ahead of print]

[15] Chiloiro S, Tartaglione T, Angelini F et al. An Overview of Diagnosis of Primary Autoimmune Hypophysitis in a Prospective Single-Center Experience. Neuroendocrinology 2017; 104: 280-290

[16] Angelousi A, Cohen C, Sosa S et al. Clinical, Endocrine and Imaging Characteristics of Patients with Primary Hypophysitis. Horm Metab Res 2018; 50: 296-302

[17] Duan K, Asa SL, Winer D et al. Xanthomatous Hypophysitis Is Associated with Ruptured Rathke's Cleft Cyst. Endocr Pathol 2017; 28 : 83-90

[18] Yang C, Wu H, Bao X et al. Lymphocytic Hypophysitis Secondary to Ruptured Rathke Cleft Cyst: Case Report and Literature Review. World Neurosurg 2018; 114: 172-177
[19] Langlois F, Manea A, Lim DST et al. High prevalence of adrenal insufficiency at diagnosis and headache recovery in surgically resected Rathke's cleft cysts-a large retrospective single center study. Endocrine 2019; 63: 463-469

[20] Howlett TA, Levy M], Robertson IJ. How reliably can autoimmune hypophysitis be diagnosed without pituitary biopsy. Clin Endocrinol (Oxf) 2010; 73: 18-21

[21] Gutenberg A, Hans V, Puchner M] et al. Primary hypophysitis: Clinical-pathological correlations. Eur J Endocrinol 2006; 155: 101-107

[22] Gubbi S, Hannah-Shmouni F, Stratakis CA et al. Primary hypophysitis and other autoimmune disorders of the sellar and suprasellar regions. Rev Endocr Metab Disord 2018; 19: 335-347

[23] Honegger ], Buchfelder M, Schlaffer S et al. Treatment of Primary Hypophysitis in Germany. J Clin Endocrinol Metab 2015; 100: 3460-3469 